\title{
SAFETY ANALYSIS REPORT FOR PACKAGING - DOT-7A FIBERGLASS-COATED PLYWOOD BOX FOR TRANSURANIUM SOLID WASTE
}

\author{
Product Definition
}

Frank E. Adcock

Equipment and Materials Technology

David L. Cash

Atomics International Division

Rocky Flats Plant

P.O. Box 464

Golden, Colorado 80401

U.S. ENERGY RESEARCH AND DEVELOPMENT ADMINISTRATION CONTRACT E(29-2)-3533 


\section{DISCLAIMER}

This report was prepared as an account of work sponsored by an agency of the United States Government. Neither the United States Government nor any agency Thereof, nor any of their employees, makes any warranty, express or implied, or assumes any legal liability or responsibility for the accuracy, completeness, or usefulness of any information, apparatus, product, or process disclosed, or represents that its use would not infringe privately owned rights. Reference herein to any specific commercial product, process, or service by trade name, trademark, manufacturer, or otherwise does not necessarily constitute or imply its endorsement, recommendation, or favoring by the United States Government or any agency thereof. The views and opinions of authors expressed herein do not necessarily state or reflect those of the United States Government or any agency thereof. 


\section{DISCLAIMER}

Portions of this document may be illegible in electronic image products. Images are produced from the best available original document. 


\section{LEGAL NOTICE}

This report was prepared as an account of work sponsored by the United States Government. Neither the United States nor the Energy Research and Development Administration, nor any of their employees, nor any of their contractors, subcontractors, or their employees, makes any warranty, expressed or implied, or assumes any legal liability or responsibility for the accuracy, completeness or usefulness of any information, apparatus, product or process disclosed, or represents that its use would not infringe privately owned rights.

Printed in the United States of America

Available from the

National Technical Information Service

II. S Department of Commerce

Springfield, Virginia 22161

Price: Printed Copy $\$ 4.00$ Microfiche $\$ 2.25$ 
Printed

July 23, 1976
RFP-2460

UC-71 TRANSPORTATION OF PROPERTY AND

NUCLEAR MATERIALS

TID-4500-R64

\section{SAFETY ANALYSIS REPORT FOR PACKAGING - DOT-7A FIBERGLASS-COATED PLYWOOD BOX FOR TRANSURANIUM SOLID WASTE}

Product Definition

Frank E. Adcock

Equipment and Materials Technology

David L. Cash
SUBJECT DESCRIPTORS

Plutonium Packaging Shipping Containers

Waste Shipping
ROCKWELL INTERNATIONAL ATOMICS INTERNATIONAL DIVISION ROCKY FLATS PLANT P.O. BOX 464 GOLDEN, COLORADO 80401

Prepared under Contract E (29-2)-3533 for the Albuquerque Operations Office U.S. Energy Research and Development Administration
This report wat NOTE sponsored by the prepared as an account of work the United States nited States Government. Neither Research and Development the United States Energy their employces, nor any of their. nor any of warranty, express their employees, makes any Liability or responsibility for the or assumes any legal or usefulnes of any information appy. completeness process disclosed, or represents that its use would or infringe privately owned rights. 
RFP-2460

THIS PAGE

\section{WAS INTENTIONALLY \\ LEFT BLANK}




\section{CONTENT S}

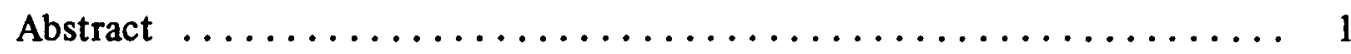

Introduction $\quad \ldots \ldots \ldots \ldots \ldots \ldots \ldots \ldots \ldots \ldots \ldots \ldots \ldots \ldots \ldots \ldots \ldots$

Purpose of Report $\ldots \ldots \ldots \ldots \ldots \ldots \ldots \ldots \ldots \ldots \ldots$

Background $\ldots \ldots \ldots \ldots \ldots \ldots \ldots \ldots \ldots \ldots \ldots \ldots \ldots \ldots \ldots \ldots \ldots \ldots$

Shipping Methods $\ldots \ldots \ldots \ldots \ldots \ldots \ldots \ldots \ldots \ldots \ldots$

Description of Container $\ldots \ldots \ldots \ldots \ldots \ldots \ldots \ldots \ldots \ldots \ldots$

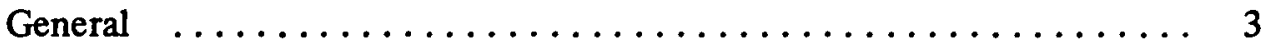

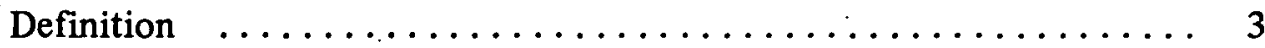

Materials of Construction $\quad \ldots \ldots \ldots \ldots \ldots \ldots \ldots \ldots$

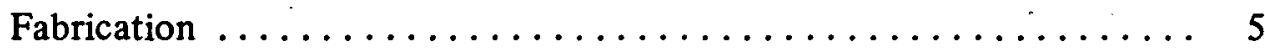

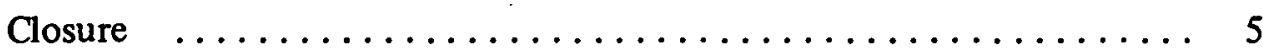

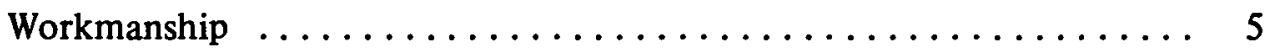

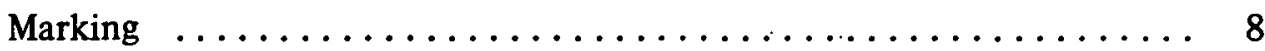

Allowable Loading $\ldots \ldots \ldots \ldots \ldots \ldots \ldots \ldots \ldots \ldots \ldots \ldots$

Package Contents....................... 8

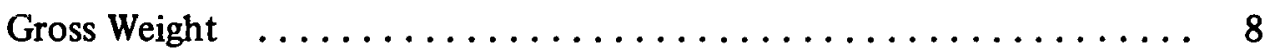

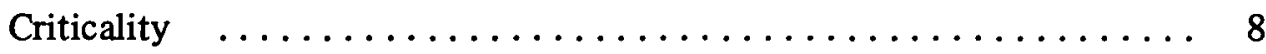

Radiation ............................ 8

Other Limitations $\ldots \ldots \ldots \ldots \ldots \ldots \ldots \ldots \ldots \ldots \ldots \ldots \ldots \ldots$

Package Evaluation $\ldots \ldots \ldots \ldots \ldots \ldots \ldots \ldots \ldots \ldots \ldots \ldots$

Requirements for DOT-7A Packages $\ldots \ldots \ldots \ldots \ldots$

Standard Requirements for All Packages ............... 9

Type A Packaging $\quad \ldots \ldots \ldots \ldots \ldots \ldots \ldots \ldots \ldots \ldots \ldots \ldots \ldots \ldots$

General Packaging and Shipment Requirements $\ldots \ldots \ldots \ldots \ldots$ 
RFP-2460

Radioactive Material in Normal Form .............. 12

Special Tests - Standards for Type A Packaging $\ldots \ldots \ldots \ldots \ldots$

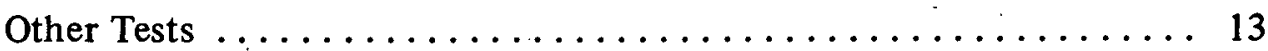

Operating Experience $\ldots \ldots \ldots \ldots \ldots \ldots \ldots \ldots \ldots \ldots \ldots \ldots \ldots \ldots \ldots \ldots \ldots$

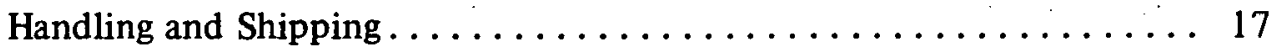

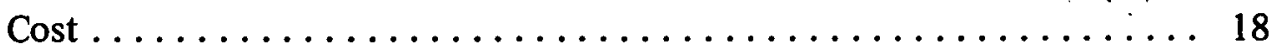

Fabrication Problems $\ldots \ldots \ldots \ldots \ldots \ldots \ldots \ldots \ldots \ldots \ldots$

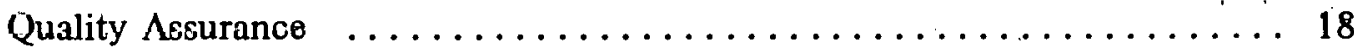

Background $\ldots \ldots \ldots \ldots \ldots \ldots \ldots \ldots \ldots \ldots$ is

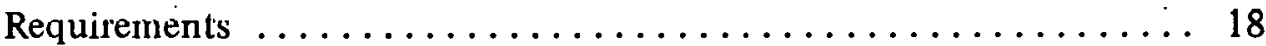

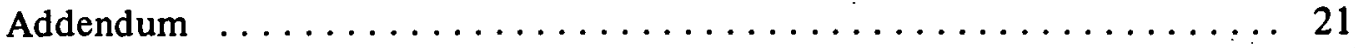




\title{
SAFETY ANALYSIS REPORT FOR PACKAGING - DOT-7A FIBERGLASS-COATED PLYWOOD BOX FOR TRANSURANIUM SOLID WASTE
}

\author{
Frank E. Adcock and David L. Cash
}

\begin{abstract}
A DOT Specification 7A, fiberglass-coated plywood box for shipping alpha-emitting transuranic waste has been developed. Nominal size for the box is 4 by 4 by 7 feet; maximum gross weight is 5000 pounds. Construction is of $3 / 4$-inch plywood with internal framing members of 2-by 4-inch lumber. The entire box, including the glued and nailed lid, is covered with a 0.12 -inch-thick fiberglass coating.
\end{abstract}

The required four-foot drop tests were passed without the box being damaged. Additional drops from 12 feet resulted in some cracking in a 2600pound box and in cracking plus some loss of contents in a test box loaded to 5700 pounds. A static load of 25,000 pounds caused no deformation or damage.

This box costs $\$ 3.50$ per cubic foot, which is approximately half the cost of steel drums with rigid polyethylene liners.

\section{INTRODUCTION}

\section{Purpose of Report}

The Department of Transportation (DOT) requires that each Specification 7A package has a safety analysis report. These reports must show that the package design, construction methods, materials, and test performance are in compliance with applicable regulations. This document constitutes the required safety analysis report. As an aid to potential users of the box design described herein, two additional sections have been provided. The first of these describes the quality assurance program for packaging as used by Rockwell International, Rocky Flats Plant. The second section concerns the Plant's shipping experience.
Also included are details about package fabrication, testing, loading, and handling.

\section{Background}

Large items of contaminated waste, such as glove boxes, for many years have been shipped to a federal waste repository in cleated boxes constructed of $3 / 4$-inch plywood. In many cases, boxes were built to fit the item being shipped. Since 1969, only 4 - by 4 - by 7 -foot boxes have been used. This was made possible by the start-up of a size reduction facility for cutting up all oversize equipment; e.g. lathes and glove boxes. In 1971, with the imposition of ERDA criteria for 20-year retreivable storage, boxes were upgraded by the addition of a 0.12 -inch coating of fiberglass reinforced polyester (FRP) covering. The FRP increased weather resistance and added considerably to the strength, fire resistance, and leak-tightness of the boxes.

To solve several fabrication problems, most notably the application of FRP around the cleats in a continuous leak-tight coating, a new flush panel box was designed. (See Figure 1.) The new box has the advantage of completely flat panels, unencumbered by exterior cleats. This gives the fabricator the option of fiberglassing each panel separately before assembly or fiberglassing the overall box following its assembly. Replacing the 1 - by 3 -inch cleats with 2 - by 4 -inch interior framing members provides stronger corner joints and reduces the tendency of fasteners to split the wood members.

\section{Shipping Methods}

Boxes may be shipped in several ways depending on each box's level of radioactive contamination. See the DOT Hazardous Materials Regulations, Code of Federal Regulations, Title 49-Transporation, Parts 170-189, for a definition of terms. 


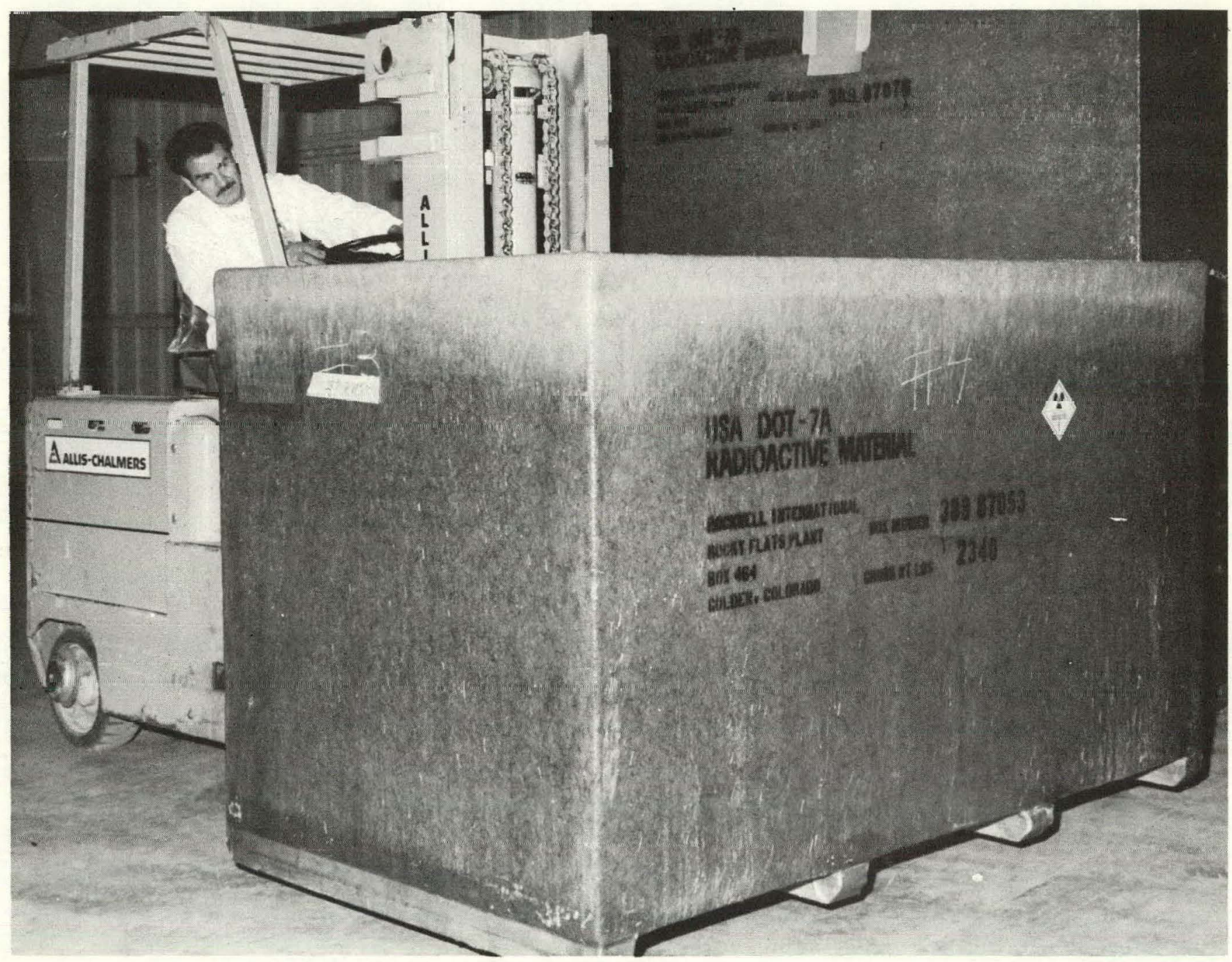

FIGURE 1. Completed flush-panel box being moved to loading area.

$19957-3$

Low Specific Activity (LSA) Boxes containing LSA waste need not have the FRP coating since neither 20-year retreivability nor performance tests are required. These packages may be shipped by commercial surface transportation. Engineering drawings for the FRP box provide for an uncoated option for this application.

Type A Quantities Type A quantities of radioactive waste may be shipped in the DOT-7A, FRP-coated box via commercial surface transportation.
Type B Quantities When greater than Type A quantities of material are to be shipped, the FRPcoated box must be overpacked in such a way that test requirements for Type B packaging can be met. At Rocky Flats, this type of waste is shipped in an ATMX-600 rail car under the provisions of DOT Special Permit 5948. Details of this shipping method may be found in RFP-2244.*

*F. E. Adcock, J. D. McCarthy. ATMX-600 Railcar Safety Analysis Report for Packaging. RFP-2244. Dow Chemical USA, Rocky Flats Division. October 14, 1974. 


\section{DESCRIPTION OF CONTAINER}

\section{General}

The Rocky Flats DOT-7A box (Figure 2) has overall dimensions of 48 inches wide by 84 inches long by 49 inches high. Skids add another three inches to the height. Construction is of $3 / 4$-inch exterior-type plywood with 2- by 4-inch framing members and skids. Boxes are assembled using adhesive and either box nails or staples. The entire box is coated with a continuous layer of FRP to a minimum thickness of 0.12 inch.

Minimum inside dimensions are 43.5 inches wide by 44 inches high by 82.5 inches long. Two liners are provided. The outer liner of 0.006 -inch polyvinyl chloride (PVC) is used primarily for contamination control during loading. An inner liner of 0.05 -inch fiberboard protects the plastic liner from punctures and tears.

A commercial box of equivalent size and rated for a 5000 pound load would use $3 / 8$-inch plywood with 1-by 4-inch framing members.* By doubling the thickness of both the plywood and frame and by overlaying the box with FRP, strength is increased several fold. Designers interested in box construction, testing, and in plywood properties can obtain many helpful publications. Several of these publications are listed in Table I.

\section{Definition}

The documents listed below constitute the specifications, acceptance criteria, and packaging procedures for the Rocky Flats DOT-7A, fiberglass-coated waste box.

\section{Required Documents}

P14434

DOT-7A Fiberglass Coated Plywood Box for > LSA Waste

P14420
Number

T210

W240

Y205

Y510

$\mathrm{Z10}$
TABLE I. Plywood design data*

Title

Plywood Design Manual: Crating

Lab Report 119A, Plywood Overlaid with Fiberglass-Reinforced-Plastic, Basic Panel Properties

Plywood Design Manual: Pallet Bins

Plywood Design Specification

Plywood for Industrial Uses Lab Report 111, Plywood Crate Tests

*Available from the American Plywood Association, 1119 A Street, Tacoma, Washington.

P14442

P14443

P14060
Fiberboard Liner

PVC Liner

Application of Fiberglass Reinforced Polyester to Plywood Boxes

$\underline{\text { Reference Documents }}$

DOT SP5948

Q2000

RFP-2244

49 CFR 178.350

\footnotetext{
*See Plywood Design Manual: Crating, as identified in Table I.
}

DOT Special Permit for ATMX Railcar

Radioactive Material Packaging Quality Assurance

ATMX Railcar, Safety Analysis Report for Packaging (SARP)

DOT Hazardous Materials Regulations, Specification 7A

Rocky Flats Waste Management Manual

$$
\begin{gathered}
\text { Section III - } \begin{array}{c}
\text { Packaging } \\
\text { Procedures }
\end{array} \\
\text { Scction IV - Opcrating and } \\
\text { Inspection } \\
\text { Procedures }
\end{gathered}
$$


FIGURE 2. Construction details of DOT-7A fiberglass-coated plywood box.

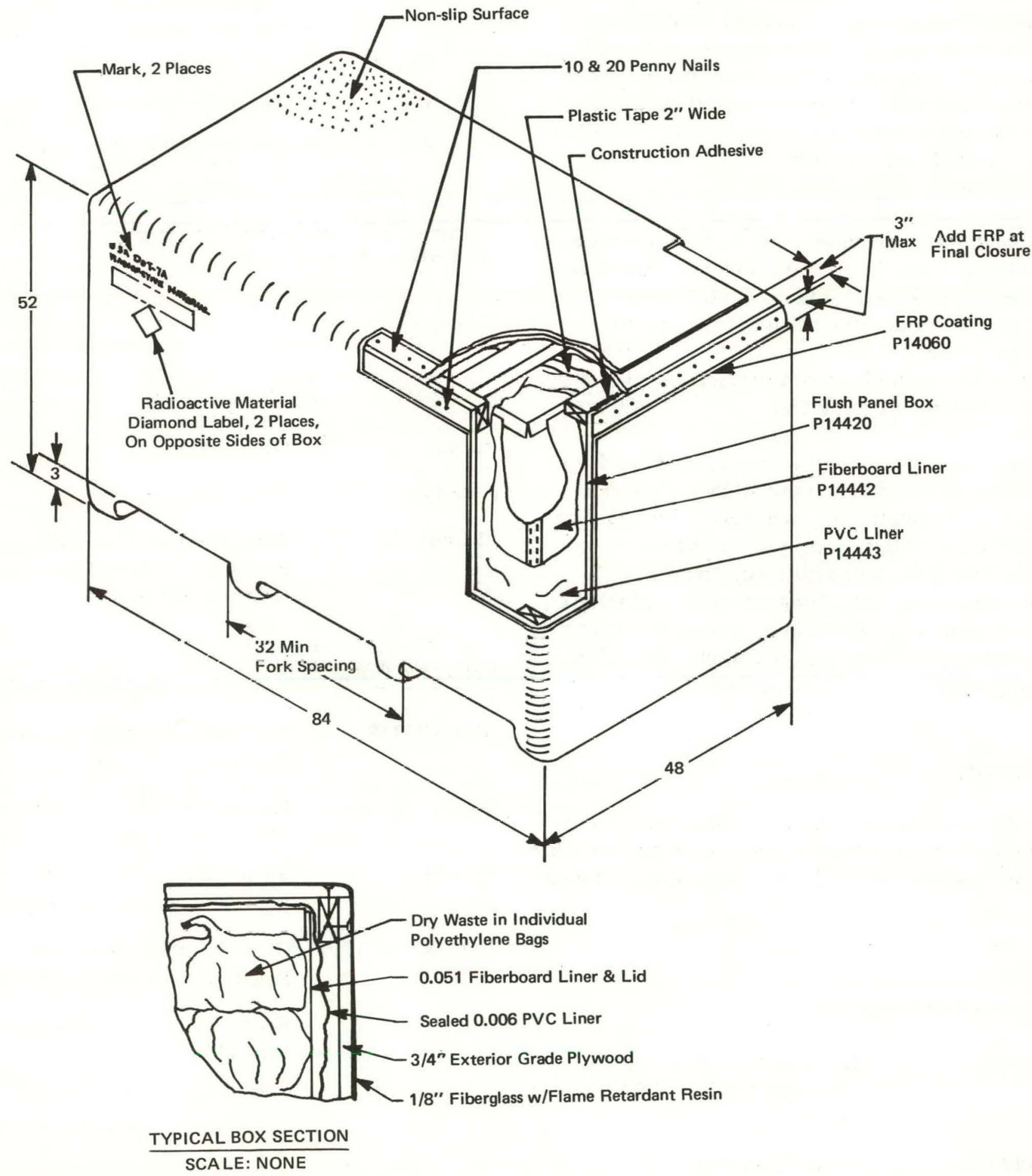




\section{Materials of Construction}

The following materials are specified for construction:

Plywood - Exterior type, unsanded, grade C-C or better, $3 / 4$-inch thick.

Framing Members - 2- by 4-inch S4S (sanded four sides), seasoned, select to be free of bark and loose knots.

Adhesive - White, water-resistant resin glue such as Elmer's, Fosco (M. L. Foss, Denver, Colorado) or equal.

Elastomeric construction adhesive No. PL-200

(B. F. Goodrich, Akron, Ohio) or approved equivalent.

Fasteners - Cement-coated box nails [ 20 penny (3.7 inch), 16 penny ( 3.2 inch), 10 penny ( $3.0 \mathrm{inch})$, and 6 penny (2.0 inch)].

Plastic-coated staples (2-inch length).

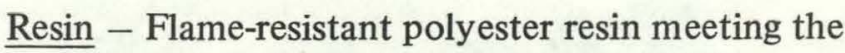
requirements of P14060, CO-REZ No. 1664

(Interplastic Corp., Minneapolis, Minn.) or equivalent.

Fiberglass - Continuous strand roving with red tracer No. 526 (PPG Industries, Pittsburg, PA) chopped in 2-inch lengths during spray-up application.

Materials are all compatible with each other; no adverse chemical or galvanic reactions are possible.

\section{Fabrication}

Box panels are fabricated by cutting $3 / 4$-inch plywood to the correct size and then adding the 2 - by 4 -inch framing members. The 2 - by 4 -inch boards are attached using a continuous path of white glue and either 6-penny nails or 2-inch staples applied through the plywood into the framing member. A nailing pattern specifying 6-inch maximum spacing is shown on the engineering drawing.

Panels are assembled into boxes in accordance with Drawing P14420-1. Plywood-to-plywood joints are fastened with a construction adhesive. Ten-penny nails or two-inch staples are then driven through the plywood into the framing members on the adjacent panel. Construction adhesive (sometimes known as panel adhesive) was chosen for this application because its thick non-hardening bead fills any irregularities in the mating surfaces and results in a waterproof, vibration proof seal.

The FRP coating may be applied to individual panels or to the assembled box. A minimum thickness of 0.12 inches is required except within 3 inches of the lid-to-body joint. This area is coated after final nailing of the lid.

Skids are bonded to the bottom of the finished box and are given a coat of resin for weather protection. There are two advantages to assembling the skids last--- (1) the smooth, flat, bottom surface of the box makes fiberglassing easier, and (2) loss of a skid because of rough handling will not cause a leak path through the FRP coating.

\section{Closure}

After loading the box and after final inspection of the contents, a fiberboard lid is added, and the PVC liner is closed and sealed with plastic tape (Figure 3). The box lid is fastened using construction adhesive and 10-penny nails. In addition, two 20-penny nails are driven through the side of the box into the end of each framing member on the lid panel. The resulting lid-to-body joints are the equivalent of three-way corners, which is the preferred method of box construction. As a final step, a 0.12 -inch coating of FRP is sprayed over the joint (Figure 4). This results in a continuous layer of FRP over the entire box. This layer provides both a leak-tight closure and a tamper-proof seal. The tough fiberglass surface resists all normal handling damage and can be opened only by using a power saw or equivalent.

\section{Workmanship}

High quality workmanship is an essential feature of each stage of box fabrication. Plywood must be cut straight and square for proper fit with mating panels. Framing members must be cut precisely 

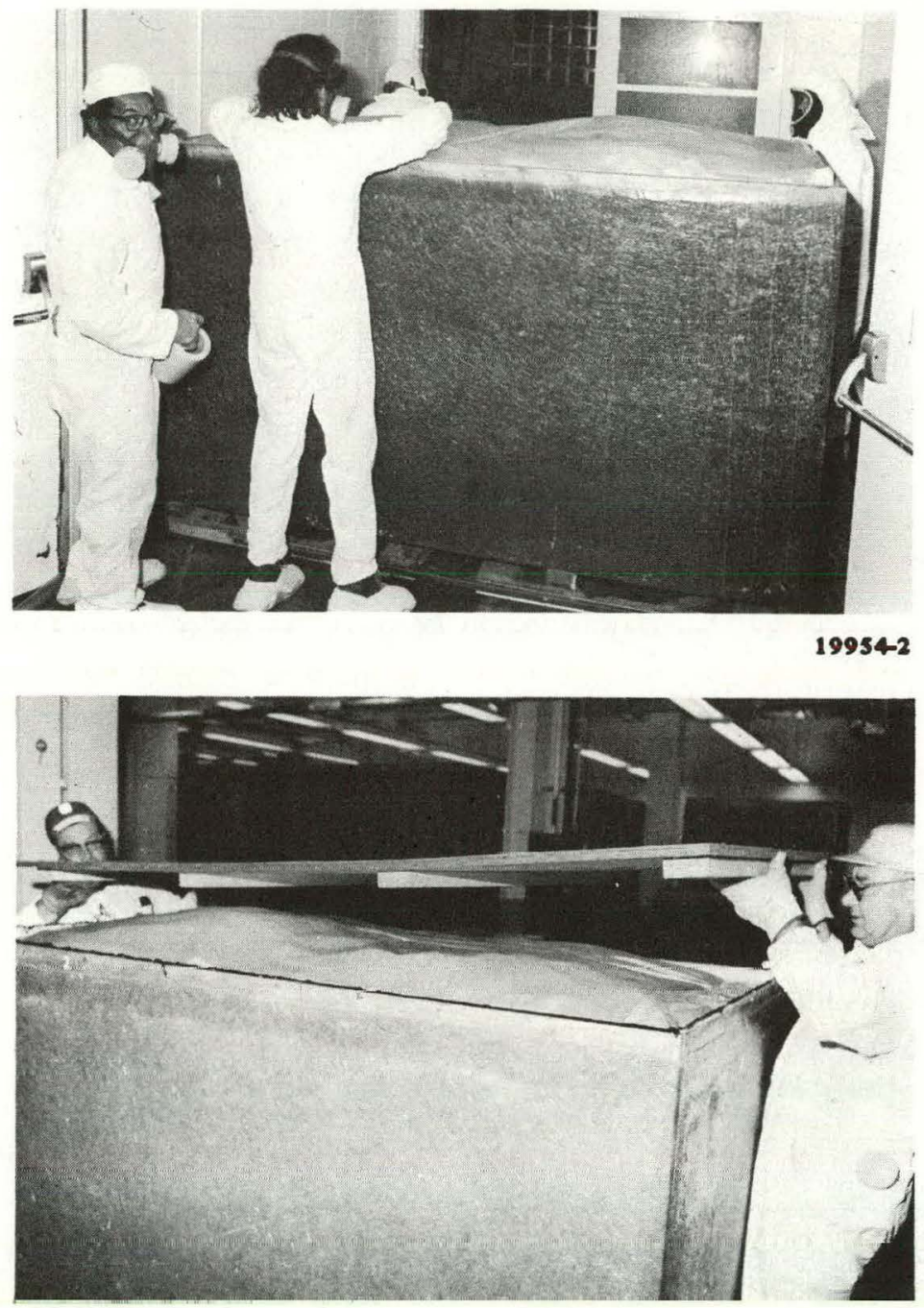

19954-7

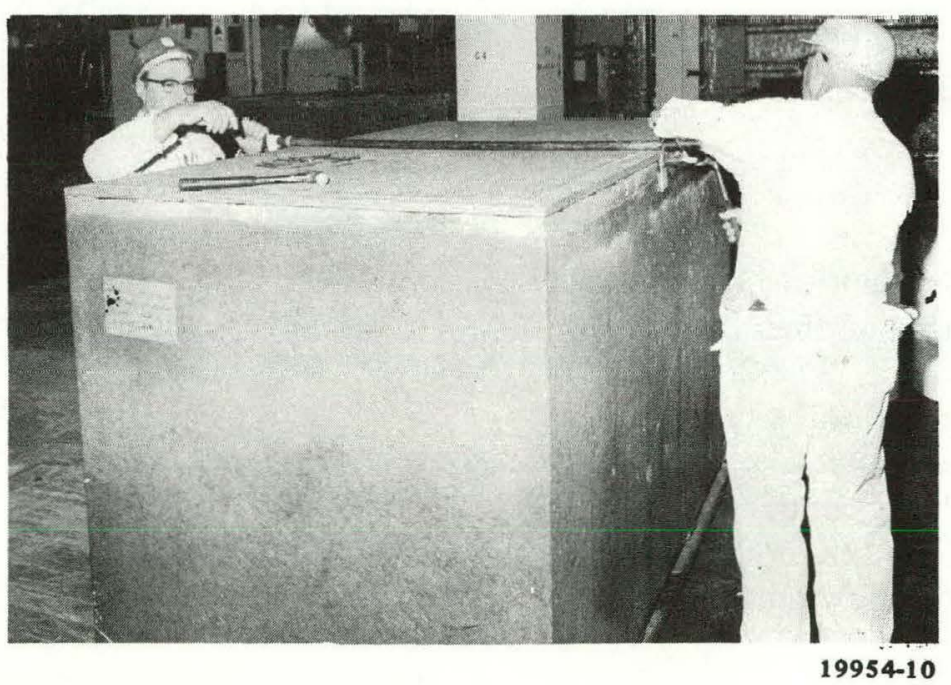

FIGURE 3. Sealing PVC liner using plastic tape (top). Adding lid to body (center); note bead of construction adhesive applied to top edges of plywood. Using furniture clamp to square box before nailing lid in place (bottom). 


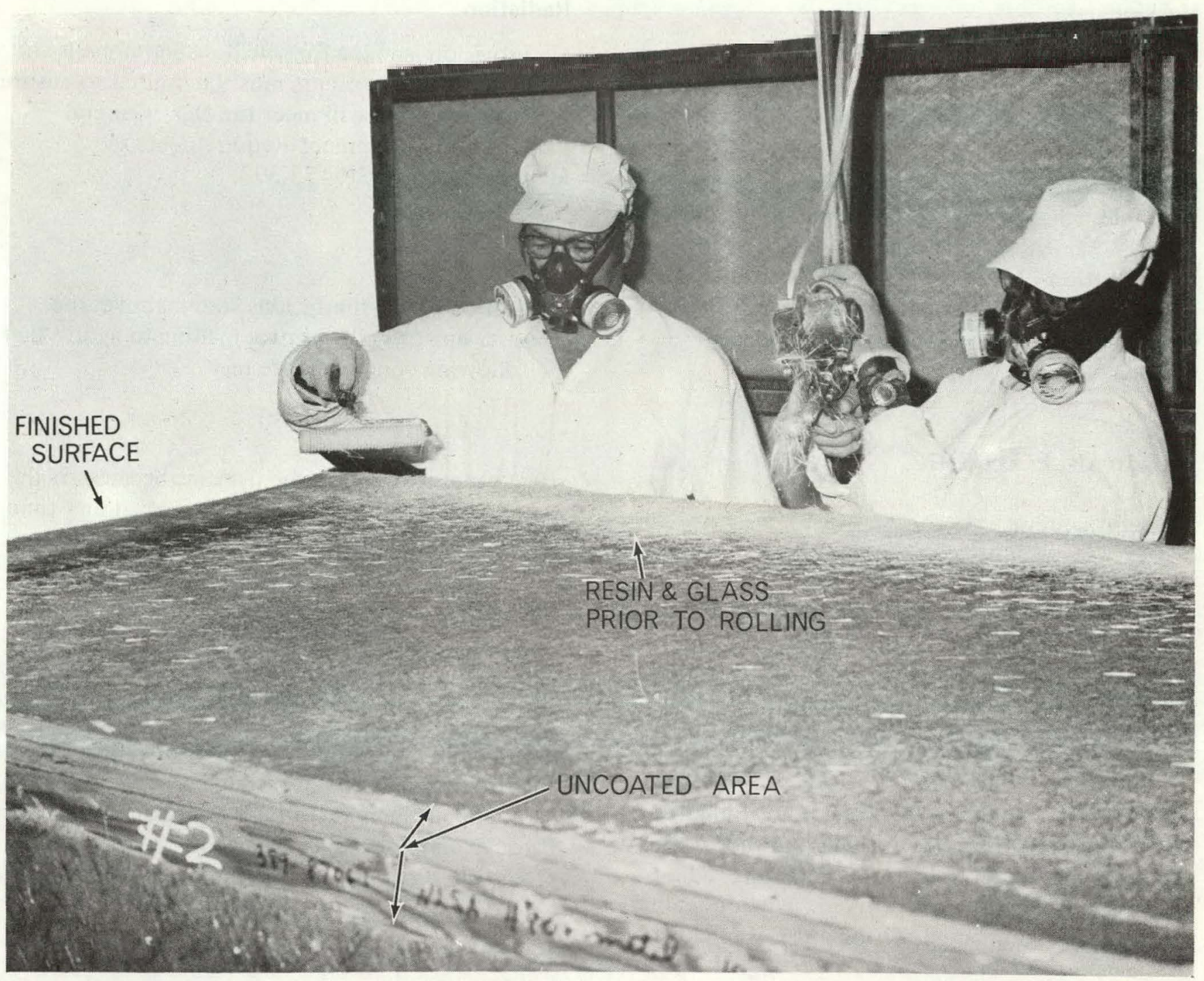

FIGURE 4. Sealing box by spray-gun application of resin and chopped glass. After

$19885-7$ rolling, the entire area is coated with clear resin to form a smooth, fiber-free surface.

and positioned correctly to ensure tight, strong joints. Proper application of the adhesives is critical and should be controlled. This control can be accomplished by skilled, knowledgable personnel and the use of adequate quality control checks.

Spray-up applications of FRP is dependent on operator skill and must be carefully controlled. Workmanship in this area is carefully inspected for exposed fibers, sharp projections, air bubbles, and similar defects. Acceptance is based on comparison with an approved standard of workmanship. FRP thickness is checked by ultrasonic inspection, and random samples are selected for additional destructive and non-destructive tests.

The box inspection form, which is a part of the engineering drawing set, requires checks for split lumber, protruding fasteners, tight corners, and other general workmanship items. All this is in addition to the standard inspection for materials and dimensions. 


\section{Marking}

Each completed box is marked in accordance with the applicable DOT requirements. "USA DOT-7A," "Radioactive Material," and the user's name and address are marked on two places on opposite sides of the box. These markings utilize characters at least 0.5 inches high. When boxes contain LSA or Type A quantities (as defined by 49 CFR) the identification "LSA" or "Type A" is also marked. Marking is done by stenciling with a contrasting color or by applying an embossed metal tag (Figure 1).

\section{ALLOWABLE LOADING}

\section{Package Contents}

The Rocky Flats DOT-7A box is intended for shipping solid waste materials contaminated with transuranic elements to a federal waste repository. These materials are items such as lathes and other machinery, glove boxes, and chemical processing equipment that are too large or bulky to fit into drum-type packages

To the maximum extent feasible, plutonium and other contaminants are removed from the waste by the best known methods. Any remaining radioactive contamination is well fixed. When possible, materials are compacted for the most efficient use uf space.

\section{Gross Weight}

A gross weight of 5000 pounds was assumed adequate for Rocky Flats' shipping needs based on actual shipping records. Test boxes were then loaded to slightly above this value, and qualification tests were performed. Test results indicate that 5000 pounds is a conservative weight limit; however, additional tests would be required prior to any shipper exceeding that value.

\section{Criticality}

Fissile material is limited to a maximum of 5 grams in each cubic foot and to 350 grams per box. With this restriction, the package is classified by DOT regulations as being non-fissile.

\section{Radiation}

No provision is made for shielding and none is permitted. Box contents must be limited to ensure that each package will meet the DOT General Packaging and Shipment Requirements as identified in 49 CFR 173.393.

\section{Other Limitations}

In addition to the limitations stated above, the box user must rigidly control loading to assure that the following conditions are met:

- No free liquids.

- Heat generated within the package because of the radioactive materials present will not, at any time during transportation (or storage), affect the efficiency of the package under the conditions normally incident to transportation.

- No pyrophoric materials.

- No significant removable surface contamination.

- There will be no mixture of gases or vapors in the package that could, through any creditable spontaneous increase of heat or pressure, or through an explosion, significantly reduce the effectiveness of the package.

- Lange, lieary items must be securely braced within the box to prevent movement.

\section{PACKAGE EVALUATION}

\section{Requirements for DOT-7A Packages}

The design, construction, and test performance of a DOT-7A package must comply with the Code of Federal Regulations, Title 49-Transportation, Hazardous Materials Regulations of the Department of Transportation, paragraph 178.350 , as given below:*

$\S 178.350$ Specification 7A; general packaging, Type A.

§ 178.350-1 General requirements. (a) Each packaging must meet all applicable requirements of § 173.24.

$\S 178.350-2$ Specific requirements. (a) Each packaging must be so designed and constructed that it meets the

*Text in small type, other than Table I, is from the Code of Federal Regulations. 
standards for Type A packaging (see $\S \S 173.389$ (j) and 173.398 (b).

\$ 178.350-3 Marking. (a) Marking on the outside of each packaging as follows: "USA DOT-7 A Type A" and "Radioactive Material."

(b) Marking to conform with $\S 173.24$.

The package drawing listed in the section on Product Definition specifies the type of marking to use and complies with Paragraph 178.350-3 and 173.24. When the content of a box is greater than Type A quantity, the words "Type A" are omitted from the package identification.

Directly or by reference, Specification $7 \mathrm{~A}$ requires compliance with the following CFR paragraphs:

173.24

$173.389(j)$

173.393

173.395 (a) (1)

$173.398(b)$
Standard Requirements for All Packages

Type A Packaging

General Packaging and Shipping Requirements

Radioactive Material in Normal Form Specification 7A

Standards for Type A Packaging

These requirements are given below along with the analysis showing how the Rocky Flats box is in compliance.

\section{Standard Requirements for All Packages}

§ 173.24 Standard requirements for all packages. (a) Each package used for shipping hazardous materials under this chapter shall be so designed and constructed, and its contents so limited, that under conditions normally incident to transportation-

(1) There will be no significant release of the hazardous materials to the environment;

(2) The effectiveness of the packaging will not be substantially reduced; and

(3) There will be no mixture of gases or vapors in the package which could, through any credible spontaneous increase of heat or pressure, or through an explosion, significantly reduce the effectiveness of the packaging.

Tests performed and described in a later section show that the Rocky Flats DOT-7A waste package passed all required tests without leakage or a reduction in effectiveness. Package loading procedures must limit waste to those materials that will comply with Paragraph 173.24 (a) (3) as previously identified.

(b) Materials for which detailed specifications for packaging are not set forth in this part must be securely packaged in strong, tight packages meeting the requirements of this section.

(c) Packaging used for the shipment of hazardous materials under this chapter shall, unless otherwise specified or exempted therein, meet all of the following design and construction criteria:

(1) Each specification container shall be marked in an unobstructed area with letters and numerals identifying that specification (e.g., ICC-6J, DOT-6L, DOT MC 306, ICC-105A200-F);

(i) The marking is a certification that the packaging complies with all specification requirements.

(ii) The name and address or the symbol of the manufacturer, or the user, who assumes responsibility for compliance with the specification requirements, shall be included. Symbol letters must be registered with the Bureau of Explosives. Duplicate symbols are not authorized.

(iii) The markings shall be stamped, embossed, burned, printed, or otherwise marked on the packaging to provide adequate accessibility, permanency, and contrast so as to be readily apparent and understood.

(iv) Unless otherwise specified, letters and numerals shall be at least $1 \frac{1}{2}$ inch high.

(v) Packaging which does not comply with the applicable specification listed in Parts 178 and 179 must not be marked to indicate such compliance.

(2) Steel used shall be low-carbon, commercial quality steel. Stainless, open hearth, electric, basic oxygen, or other similar quality steels are acceptable. Steel sheets of specified gauges shall comply with the following:

$\begin{array}{ccc}\begin{array}{c}\text { Nominal } \\ \text { thickness } \\ \text { (inches) }\end{array} & \begin{array}{c}\text { Minimum } \\ \text { thickness } \\ \text { (inches) }\end{array} \\ 0.1046 & & 0.0946 \\ 0.0897 & & 0.0817 \\ 0.0747 & & 0.0677 \\ 0.0673 & & 0.0603 \\ 0.0598 & & 0.0533 \\ 0.0538 & & 0.0478 \\ 0.0478 & & 0.0428 \\ 0.0418 & & 0.0378 \\ 0.0359 & & 0.0324 \\ 0.0299 & & 0.0269 \\ 0.0269 & & 0.0239 \\ 0.0239 & & 0.0209 \\ 0.0179 & & 0.0159 \\ 0.0149 & 0.0129 \\ 0.0120 & 0.0110\end{array}$


(3) Lumber used shall be well seasoned, commercially dry, and free from decay, loose knots, knots that would interfere with nailing, and other defects that would materially lessen the strength.

(4) Welding and brazing shall be performed in a workmanlike manner using suitable and appropriate techniques, materials, and equipment.

(5) Packaging materials and contents shall be such that there will be no significant chemical or galvanic reaction among any of the materials in the package.

(6) Closures shall be adequate to prevent inadvertent leakage of the contents under normal conditions incident to transportation. Gasketed closures shall be fitted with gaskets of efficient material which will not be deteriorated by the contents of the container.

(7) Nails, staples, and other metallic devices shall not protrude into the interior of the outer packaging in such a manner as to be likely to cause failures.

(8) The nature and thickness of the packaging shall be such that friction during transport does not generate any heating likely to decrease the chemical stability of the contents.

(9) Polyethylene used must be of a type compatible with the lading and must not be permeable to an extent that a hazardous condition could be caused during transportation and handling.

(d) For specification containers, compliance with the applicable specifications in Parts 178 and 179 shall be required in all details, except as otherwise provided in this chapter.

Paragraph 173.24 (b) through (d) gives the requirements for good workmanship and for quality materials. The engineering drawings listed in the section on Product Definition control both workmanship and materials so as to meet or exceed the DOT standards. It already has been noted that all marking is in compliance. The entire box, including the closure, is sealed by a continuous coating of FRP that provides a leak-proof, tamperproof package. There will be no galvanic or chemical reaction between the wood and FRP or between these materials and the liners (PVC and fiberboard) and contents.

\section{'Iype A Packaging}

\subsection{Definitions.}

(j) "Type A packaging" means packaging which is designed in accordance with the general packaging requirements of $\S \S 173.24$ and 173.393 , and which is adequate to prevent the loss or dispersal of the radioactive contents and to retain the efficiency of its radiation shielding properties if the package is subject to the tests prescribed in $\S 173.398$ (b).

See Paragraphs 173.393 and 173.398 (b), which follow, for analysis. Also note that no radiation shielding is needed and none is used for this type of waste package.

\section{General Packaging and Shipment Requirements}

173.393 General packaging and shipment requrements. (a) Unless otherwise specified, all shipments of radioactive materials must meet all requirements of this section, and must be packaged as prescribed in $\S 173.391$ through 173.396

Only Paragraphs 173.393 and 173.395 (a) (1) are applicable. Other paragraphs are applicable to subject areas such as "Small Quantities" and "Low Specific Activity."

(b) The outulute of eds pach age must innorpnonte a feature such as a seal, which is not readily breakable and which, while intact, will be evidence that the package has not been illicitly opened.

The entire box is coated with a continuous layer of FRP and cannot be opened without sawing through the fiberglass and plywood.

(c) The smallest outside dimension of any package must be 4 inches or greater.

The box size is 4 - by 4 - by 7 -feet.

(d) Each radioactive material must be packaged in a packaging which has been designed to maintain shiclding efficiency and leak tlghtriess, so llial, uniei conditions normally incident to transportation, there will be no release of radioactive material. If necessary, additional suitable inside packaging must be used. Each package must be capable of meeting tlee standaids in \& \& 173.398 (b) and 173.24.

(1) Internal bracing or cushioning, where used, must be adequate to assure that, under the conditions normally incident io iranspurlatiun, thi distance from the inner con. tainer or radioactive material to the outside wall of the package remains within the limits for which the package design was based, and the radiation dose rate external to the package does not exceed the transport index number shown on the label. Inner shield closures must be positively secured to prevent loss of the contents.

No shielding is necessary for the types of waste being packaged at Rocky Flats, and none is used. The box will remain leak tight under conditions of normal transport as detailed under Paragraph 173.398 (b), which is reprinted later in this report. Fissile material within the package is well distributed because of the nature of the waste material. There is no possible way to shift or concentrate 
radioactive and fissile material to constitute a criticality or radiation hazard.

(e) The packaging must be designed, constructed, and loaded so that during transport:

(1) The heat generated within the package because of the radioactive materials present will not, at any time during transportation, affect the efficiency of the package under the conditions normally incident to transportation, and

(2) The temperature of the accessible external surfaces of the package will not exceed $122^{\circ} \mathrm{F}$. in the shade when fully loaded, assuming still air at ambient temperature. If the package is transported in a transport vehicle consigned for the sole use of the consignor, the maximum accessible external surface temperature shall be $180^{\circ} \mathrm{F}$.

In Rocky Flats waste, the low levels and wide distribution of heat-generating radioactive materials within the package are such that there is no measurable heat load.

(f) Pyrophoric materials, in addition to the packaging precribed in this subpart, must also meet the packaging requirements of $\S 173.134$ or $\S 173.154$. Pyrophoric radioactive liquids may not be shipped by air.

There are no pyrophoric materials shipped. Any plutonium present is in a stable, non-pyrophoric form.

(g) Liquid radioactive material in Type A quantities must be packaged in or within a leak-resistant and corrosion-resistant inner containment vessel.

Packaging procedures assure that there will be no liquids within the package.

(h) There must be no significant removable radioactive surface contamination on the exterior of the package (see § 173.397).

Heal th Plyysics monitoring of each package prior to shipment assures that removable surface contamination is less than the limits given in Paragraph 173.397.

(i) Except for shipments described in paragraph (j) of this section, all radioactive materials must be packaged in suitable packaging (shielded, if necessary) so that at any time during the normal conditions incident to transportation the radiation dose rate does not exceed 200 millirem per hour at any point on the external surface of the package, and the transport index does not exceed 10.
All packages are shipped by exclusive-use vehicle in accordance with paragraph (j) below.

(j) Packages for which the radiation dose rate exceeds the limits specified in paragraph (i) of this section, but does not exceed at any time during transportation any of the limits specified in paragraphs (j) (1) through (4) of this section may be transported in a transport vehicle which has been consigned as exclusive use (except aircraft). Specific instructions for maintenance of the exclusive use (sole use) shipment controls must be provided by the shipper to the carrier. Such instructions must be included with the shipping paper information:

(1) 1,000 millirem per hour at 3 feet from the external surface of the package (closed transport vehicle only);

(2) 200 millirem per hour at any point on the external surface of the car or vehicle (closed transport vehicle only);

(3) Ten millirem per hour at any point 2 meters (six feet) from the vertical planes projected by the outer lateral surface of the car or vehicle; or if the load is transported in an open transport vehicle, at any point 2 meters (six feet) from the vertical planes projected from the other edges of the vehicle.

(4) 2 millirem per hour in any normally occupied position in the car or vehicle, except that this provision docs not apply to private motor carriers.

Prior to each shipment, the exclusive-use truck or rail car is monitored at the external surface and at a distance of three feet. Radiation at the surface is well within the 200-millirem-per-hour limit; radiation levels at three feet are virtually background readings.

(k) When radioactive materials are loaded by the shipper into a transport vehicle assigned for the sole use of that shipper, the shipper must observe all applicable requirements of Part 174,175 , or 177 , as appropriate.

Parts 174, 175, and 177 concern the loading, unloading, placarding, and handling of rail cars and motor vehicles. The Traffic Department at Rocky Flats assures that all shipments are in compliance; however, a detailed analysis is beyond the scope of this document.

(l) Packages consigned for export are also subject to the regulations of the foreign governments involved in the shipment. See $\S \S 173.8,173.9$, and 173.393b. (The regulations of the International Atomic Energy Agency (IAEA) are used by most foreign governments.)

Not applicable.

(m) Prior to the first shipment of any package, the shipper shall determine by examination or appropriate test that: 
(1) The packaging meets the specified quality of design and construction; and

(2) The effectiveness of the shielding and containment, and, where necessary, the heat transfer characteristics of the package are within the limits applicable to or specified for the package design.

Inspection of each package prior to use is detailed in the section entitled Quality Assurance.

(n) Prior to each shipment of any package, the shipper shall insure by examination or appropriate test that:

(1) The package is proper for the contents to be shipped;

(2) The packaging is in unimpaired physical condition except for superficial marks;

(3) Each closure device of the packaging, including any required gasket, is properly installed and secured and free of defects;

(4) For a fissile material, and moderator and neutron absorber, if required, is present in proper condition;

(5) Any special instructions for filling, closing, and preparation of the package for shipment have been followed;

(6) Each closure, valve, and any other opening of the containment system through which the radioactive content might escape is properly closed and sealed;

(7) Each package containing liquid in excess of a Type A quantity and destined for air shipment is tested to demonstrate that it is leak tight under an amblent atmospheric pressure differential of at least 0.5 atmosphere (absolute) (7.3 p.s.i.a. or $0.5 \mathrm{~kg} . / \mathrm{cm}$.); the test may be conducted on the entire containment system or on any receptacle or vessel within the containment system, as appropriate to determine compliance with the requirement;

(8) If the maximum normal operating pressure of a package is likely to exceed $0.35 \mathrm{~kg} . / \mathrm{cm}^{2}$ (gage), the internal pressure of the containment system will not exceed the design pressure during transportation; and

(9) Extcrnal radiation and contamination levels are within the allowable limits.

A "Packing Check List" for each type of waste package lists applicable items given by (n). See the Quality Assurance section for details. Items (4), (7), and (8) do not apply.

(o) No person may offer for transportation a package of radioactive materials until the temperature of the packaging system has reached equubrium (see also paragraph (e) of this section) unless, for the specific contents, he has ascertained that the maximum applicable surface temperature limits cannot be exceeded.

Not applicable. There will be no measurable heat rise on the surface of the package because of internal heating.

\section{Radioactive Material in Normal Form}

$\S 173.395$ Radioactive material in normal form.

(a) In addition to the applicable requirements of $\S \S$
173.24 and 173.393, a Type A quantity of normal form radioactive material must be packaged as follows:

(1) Specification 7A ( $\$ 178.350$ of this subchapter) Type A general packaging. Each shipper of a specification $7 \mathrm{~A}$ packaging must maintain on file for at least one year after the latest shipment, and be prepared to provide the Department, a complete certification and supporting safety analysis demonstrating that the construction methods, packaging design, and materials of construction are in compliance with the specification. This requirement is effective December 31, 1975.

This report constitutes the required safety analysis for the Rocky Flats DOT-7A fiberglass coated waste box.

\section{Special Tests - Standards for Type A Packaging}

$\S 173.398$ Special tests.

(b) Standards for Type A packaging:

(1) Type A packaging must be so designed and constructed that, if it were subject to the envirommental and test conditions prescribed in this paragraph:

(i) There would be no release of radioactive material from the package;

(ii) The effectiveness of the packaging would not be substantially reduced; and

(iii) There would be no mixture of gases or vapors in the package which could, through any credible increase of pressure or an explosion, significantly reduce the effectiveness of the package.

The details that follow concern package performance when the package is subjected to environmental and test conditions. It is the responslbility of the organization packaging the waste to control the waste contents so as to comply with Subparagraph (iii).

(2) Environmental conditions:

(i) Heat. Direct sunlight at an ambient temperature of $130^{\circ} \mathrm{F}$. in still air.

(ii) Cold. An ambient temperature of $-40^{\circ} \mathrm{F}$. in still air and sliade.

(iii) Reduref pressure. Ambient atmospheric pressure of 0.5 at mosphere (absolute) (7.3 p.s.i.a.).

(iv) Vibration. Vibration normally incident to transportation.

Since 1972, hundreds of packages of similar design have been loaded, shipped, and stored in typical Colorado and Idaho environments that range in temperature from $105^{\circ} \mathrm{F}$ to about $-25^{\circ} \mathrm{F}$. No cracking or leaks have been noted, and no contamination incidents have been reported. All materials used function effectively at the required 
test temperatures. The reduced pressure test is applicable only to packages that will be shipped by air. The fiberglass coated plywood box is limited to surface transportation. There is no component of the box that can be damaged by vibrations encountered in the transportation cycle. This has been demonstrated by the hundreds of packages successfully shipped without incident.

(3) Test conditions: The packaging shall be subject to all of the following tests unless specifically exempted therefrom, and also to the consecutive application of at least two of the following tests from which it is not specifically exempted:

(i) Water spray. A water spray heavy enough to keep the entire exposed surface of the package except the bottom continuously wet during a period of 30 minutes. Packages for which the outer layer consists entirely of metal, wood, ceramic, or plastic, or combinations thereof, are exempt from the water spray test.

(ii) Free drop. Between $1^{1 / 2}$ to $2^{1 / 2}$ hours after the conclusion of the water spray test, a free drop through a distance of 4 feet onto a flat essentially unyielding horizontal surface, striking the surface in a position for which maximum damage is expected.

(iii) Corner drop. A free drop onto each corner of the package in succession, or in the case of a cylindrical package onto each quarter of each rim, from a height of 1 foot onto a flat essentially unyielding horizontal surface. This test applies only to packages which are constructed primarily of wood or fiberboard, and do not exceed 110 pounds gross weight, and to all Fissile Class II packagings.

(iv) Penetration. Impact of the hemispherical end of a vertical steel cylinder $1 \frac{1}{4}$ inches in diameter and weighing 13 pounds, dropped from a height of 40 inches onto the exposed surface of the package which is expected to be most vulnerable to puncture. The long axis of the cylinder shall be perpendicular to the package surface.

(v) Compression. For packages not more than 10,000 pounds in weight, a compressive load equal to either five times the weight of the package or 2 pounds per square inch multiplied by the maximum horizontal cross section of the package, whichever is greater. The load shall be applied during a period of 24 hours, uniformly against the top and bottom of the package in the position in which the package would normally be transported.

The FRP coated box is exempt from the water spray and corner drop tests.

Free drop tests were conducted on two sealed boxes loaded with gravel to gross weights of 2600 and 5700 pounds. The lighter weight represents the average weight of Rocky Flats waste boxes; the heavier box is the greatest gross weight expected in a shipment. When dropped from the specified height of four feet, both boxes remained intact with no evidence of damage. A large concrete pad was the impact target for all drop tests.

The 2600-pound box was dropped four more timestwice from a height of 6 feet and twice from 12 feet. The 6-foot drops on the top and bottom long edges of the box resulted in no damage to the box. When dropped from 12 feet, the end skid broke off (Figure 5) but the box remained sound.

Figure 6 shows the 5700-pound box after being dropped from 12 feet and hitting on its lower edge. The bottom and side edges split open, and there was some loss of contents. This gross over-test was performed only to determine the height of drop where failure of a heavily loaded box could be expected. For a comparison, an older style non-fiberglassed box weighing 5000 pounds was dropped from three feet resulting in the massive damage shown in Figure 7.

A 13-pound rod of 1.25-inch diameter was dropped from a height of 40 inches onto the box lid. The long axis of the cylinder was perpendicular to the lid when dropped. No measurable damage was caused by the impact of the hemispherical end of that rod.

As shown in Figure 8, twenty-five thousand pounds of steel was stacked on a sealed FRP-coated box. The steel remained on the container top for a 24-hour period with no measurable deformation or damage to the box.

\section{Other Tests}

Previous work at Rocky Flats* demonstrated the superior fire-resistant properties of an FRP-coated box as compared with a bare plywood box. Both types of boxes were exposed to a 5-by 7 -inch radiant heat panel that produced a surface temperature of $1290^{\circ} \mathrm{F}\left(700^{\circ} \mathrm{C}\right)$. Bare $3 / 4$-inch plywood ignited in 20 seconds and burned through

*J. W. Lindsay, W. E. Domning, private communication, Dow Chemical U.S.A., Rocky Flats Division, 1972. 
FIGURE 5. Results of drop tests on 2600-pound box.

19499-9

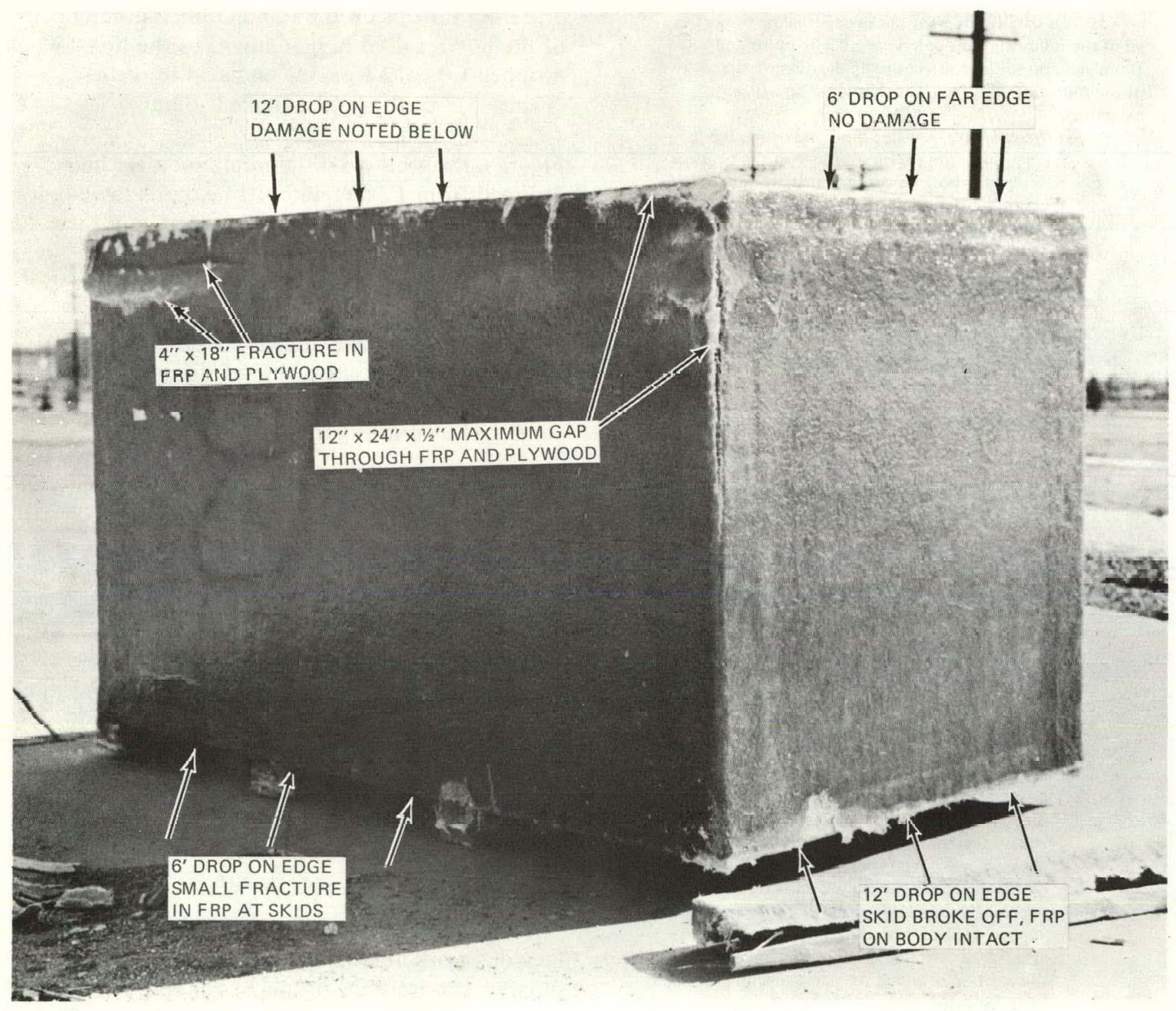




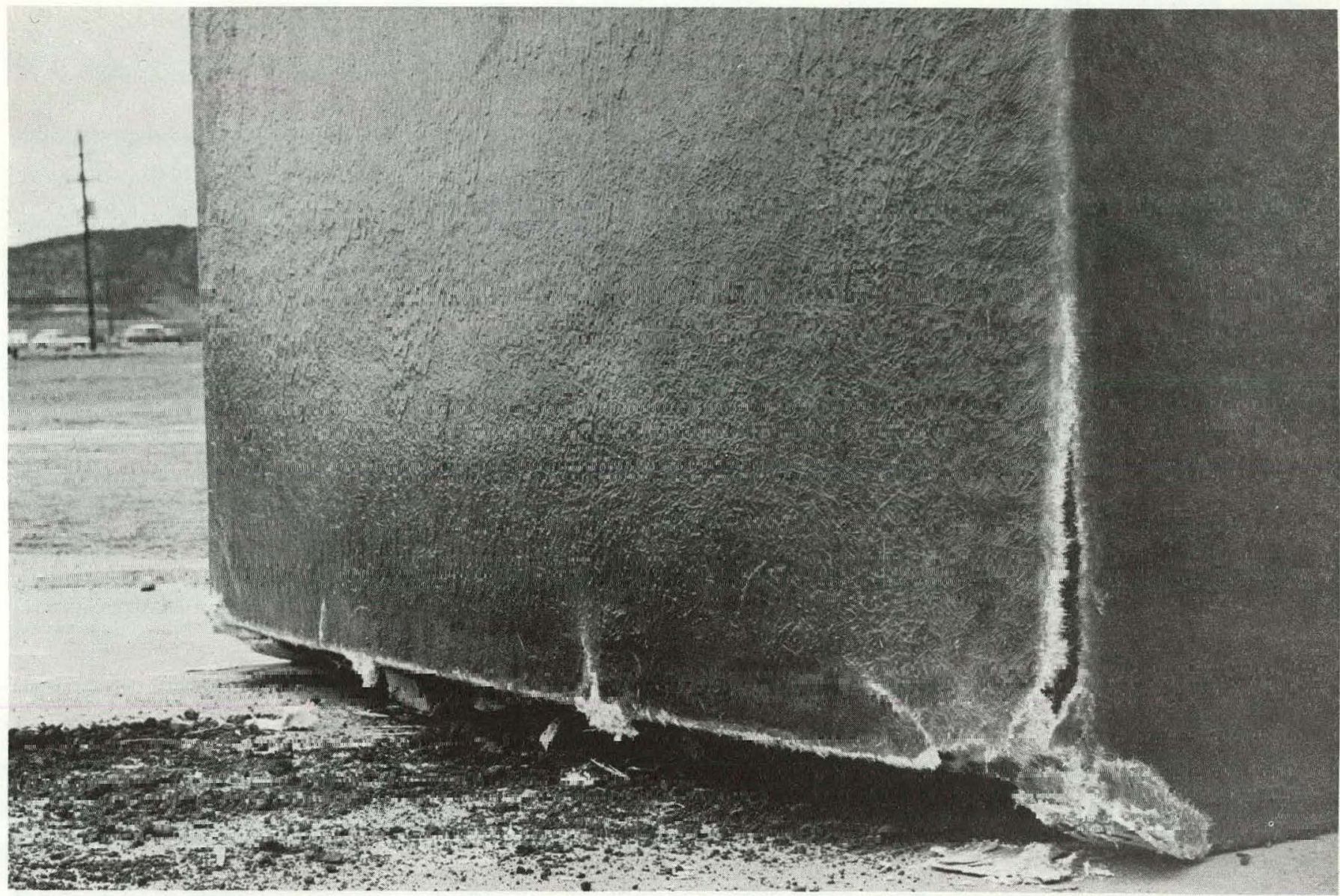

FIGURE 6. Edge drop of 5700-pound box from 12 feet resulted in some loss of contents. Similar drop from four feet dented skids slightly but body remained sound.

FIGURE 7. Old style, uncoated box weighing 5000 pounds showed massive damage when dropped from three feet.

19489-1

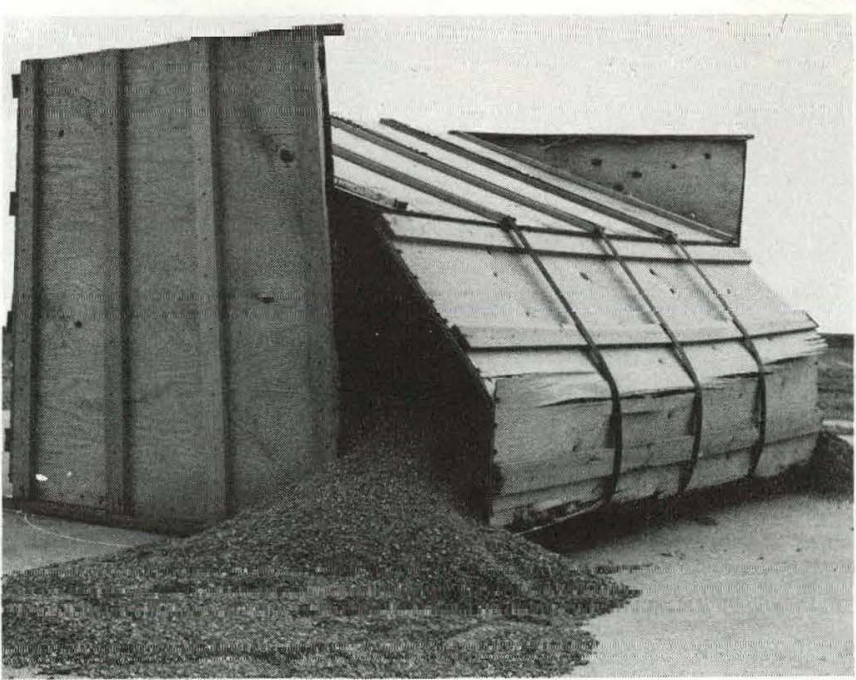

FIGURE 8. Steel sheet and plate with a total weight of 25,000 pounds was left in place for 24 hours to meet the DOT-required compression test of five times maximum gross weight.

19414-3

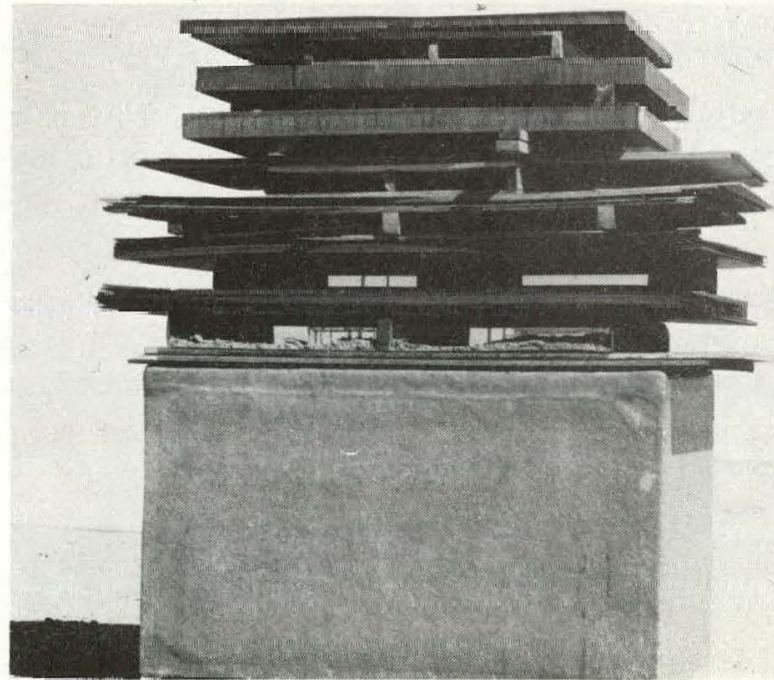




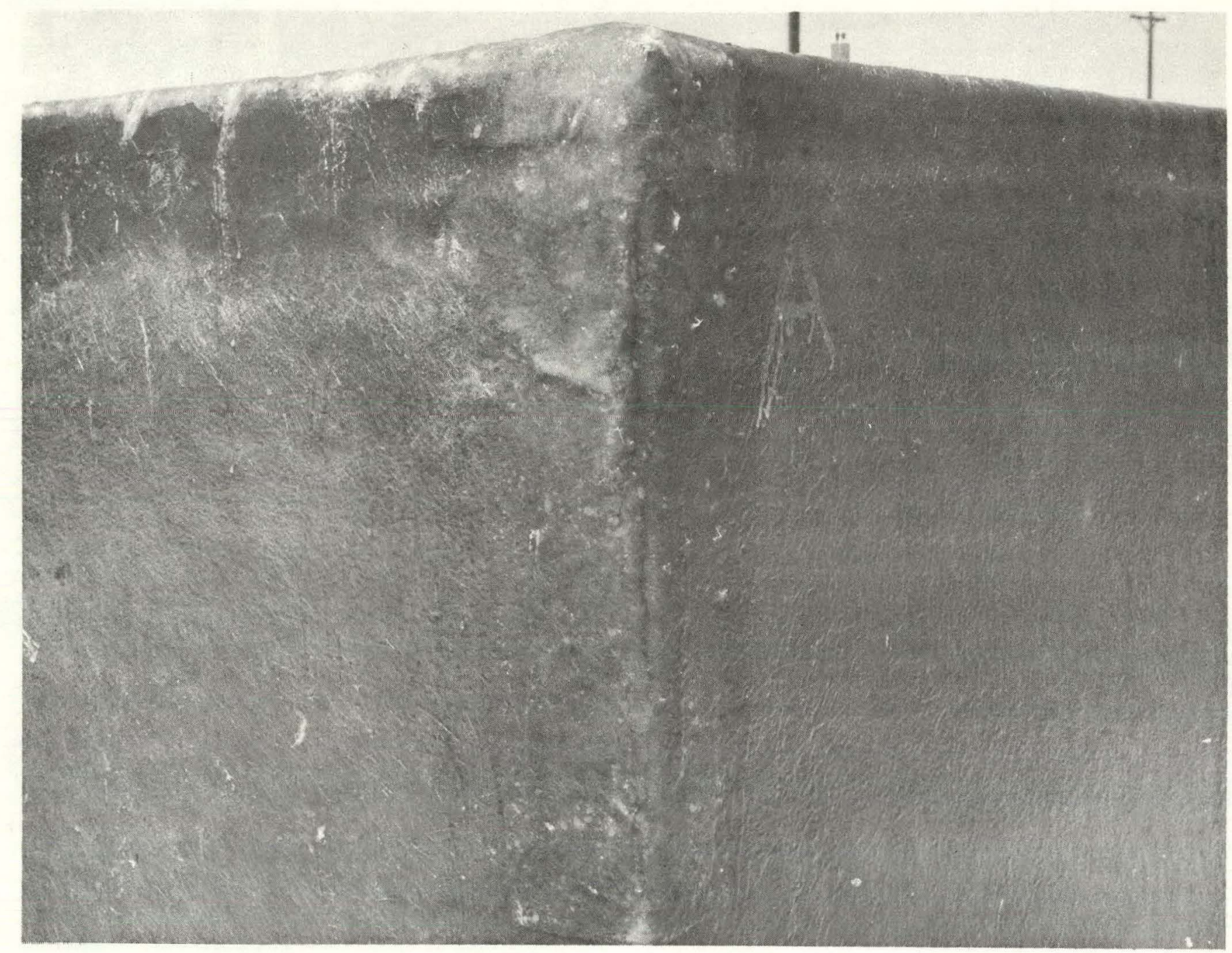

FIGURE 9. Upper right hand corner of damaged box shown in Figure 5 atter field repair.

19582-3

The $12-\times 24-\times 1 / 2$-inch crack has been sealed using fiberglass matte and polyester resin.

in 31 minutes. The FRP-coated box ignited in 60 seconds with burn-through of the plywood occuring in 2.5 hours.

To demonstrate the feasibility of field repairing boxes damaged in a serious accident, the test boxes were resealed with an application of fiberglass matte and polyester resin. Portable equipment was used for that repair. The crack along the bottom of the 5700 pound box (Figure 6) was patched by two men in less than 45 minutes. Figure 9 shows a close-up of the 12- by 24-inch fracture in the 2600 pound box (Figure 5) after repair. Except for a slightly rougher finish, all repaired surfaces were in like-new condition.

To ensure containment capabilities of the FRPcoated box, a leak-testing procedure has been developed that utilizes a mass spectrometer, helium-leak detector. A sampling probe from the leak detector is inserted into a vacuum pump line that is installed in a sealable test lid. When the box pressure is reduced to a vacuum of four to six inches of water, a light helium spray is directed around the exterior of the container. Three flushpaneled boxes, two fabricated at Rocky Flats and 


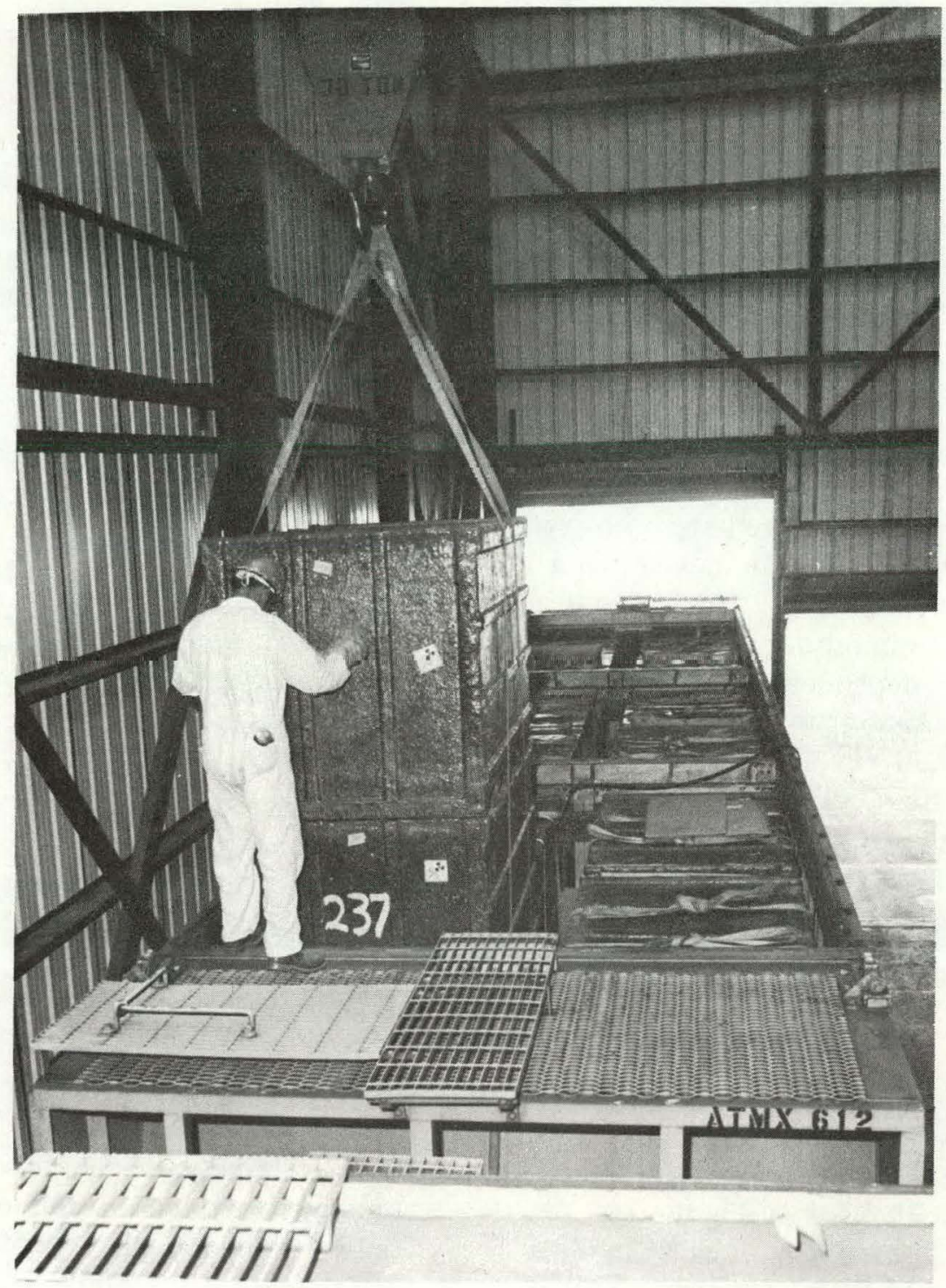

19622-7

FIGURE 10. Old-style boxes with external cleats being loaded into ATMX-600 series rail car. Boxes are handled two at a time; slings are left in place to facilitate unloading.

one that was vendor-supplied, were found to be leak-tight by this method. Induced leaks, made by drilling a 0.050 -inch hole through the FRP at a plywood joint, were detectable on the same boxes.

Leak tests also have been performed by immersing the lower portion of the box in water and observing any water leaking in; also, by filling the box with 18 inches of water and observing any leaks.
Although both tests are adequate, both have certain disadvantages, and neither are recommended.

\section{OPERATING EXPERIENCE}

\section{Handling and Shipping}

Since 1969, Rocky Flats has been shipping waste boxes by ATMX-600 series rail car. As shown in Figure 10, boxes are loaded two-high with eight 
boxes in each of three bays for a total of 24 boxes per car. The length of each bay has been adjusted to equal the length of two boxes plus six inches clearance. Inflatable dunnage bags are placed in the six-inch gap between each pair of boxes to restrain the load tightly against the steel and timber bulkheads. A crew consisting of a foreman, crane operator, and two helpers can load and inspect a car in approximately 3.5 hours.

There have been no reportable transportation incidents involving contamination, leakage, or damage to boxes; however, there have been several instances where skids have been knocked off or damaged because of careless fork truck operation, improper handling, or improper box fabrication. Since the skids are independent of the sealed box, no leakage resulted, and repair of the skids was accomplished easily. To avoid abrading the box edges, nylon slings are used instead of steel cables. Slings are left in place around each pair of boxes to facilitate unloading. These are returned in the empty ATMX car.

\section{Cost}

FRP-coated boxes are purchased from local firms on a competitive bid basis. Because of wide fluctuation in plywood costs during the 1973-1975 period, Rocky Flats purchased plywood in bulk from GSA and furnished the necessary quantities to the box fabricator. Similarily, polyester resin was also furnished by Rocky Flats because of price fluctuation and periods of non-availability.

Approximate box prices are as follows (1975 data):

\begin{tabular}{|c|c|}
\hline $\begin{array}{l}\text { Box fabrication, FRP application, } \\
\text { and lumber }\end{array}$ & $\$ 180.00$ \\
\hline Plywood & 51.00 \\
\hline Polyester resin & 96.00 \\
\hline Total & $\$ 327.00$ \\
\hline
\end{tabular}

As a cost of $\$ 3.50$ per cubic foot, the FRP-coated plywood box is approximately half the cost of the alternate shipping method (steel DOT-17C drums with rigid polyethylene liners).

\section{Fabrication Problems}

Fabrication problems have been a continuing concern. The most serious problem has been minute leak paths through the fiberglass. This has been solved by the new flush panel design. Numerous minor defects such as poor-fitting fianing mcmbcrs, gaps between framing members and plywood panels, and poor workmanship in the FRP finish are caused by inexperienced help and rapid turnover at the fabricator's plant. In the past year, four firms have supplied boxes, and all have given erratic performance.

Since Rocky Flats performs 100\% receiving inspection, defective boxes can be segregated and returned to the vendor for rework or replacement; however, the cost of inspection and handling at Rocky Flats must be added to the price of the box. These costs are not unique to boxes but apply to all types of waste packaging.

\section{QUALITY ASSURANCE}

\section{Background}

ERDA Manual Chapter 0529 requires that each contractor establish a quality assurance program for the fabrication, assembly, and testing of off-site shipping containers. The intent of this program is to assure that high quality standards are met during the fabrication, assembly, and inspection of each package.

\section{Requirements}

Listed below are the ERDA requirements for a packaging quality assurance programr. Following each requirement is the method used at Rocky Flats to comply with that requirement.

\section{RESPONSIBILITIES - ASSIGN SPECIFIC RESPONSIBILITIES TO THE USER, VENDORS, AND FABRICATORS TO ASSURE SPECIFIED QUALITY AT ALL STAGES OF CONSTRUCTION.}

At Rocky Flats, responsibilities for assuring container quality are assigned by Document Q2000, a 
quality control procedure entitled, "Radioactive Packaging Quality Assurance." Primary responsibility is assigned to individuals in Quality Engineering who supervise the preliminary determination (receiving inspection) and to Waste Management personnel who assemble the components and pack the containers. All container components are purchased from commercial suppliers or fabricators and are assembled at Rocky Flats. Certain key fabricators such as drum and box manufacturers are subject to a vendor audit conducted by a team consisting of personnel from Purchasing, Quality, and from Product Engineering. This team ensures that fabricators maintain good manufacturing and quality control methods.

ROUTINE MAINTENANCE INSPECTION PROVIDE FOR ROUTINE INSPECTION PRIOR TO THE REUSE OF ANY CONTAINER TO ENSURE THAT ALL APPLICABLE DESIGN STANDARDS HAVE BEEN MET.

This waste package is intended as a single-trip container. No reuse is allowed.

RECORDS - PROVIDE THAT QUALITY

ASSURANCE RECORDS ARE MAINTAINED IN AN AUDITABLE FILE DURING THE SERVICE LIFE OF THE CONTAINER.

Required inspection forms for package components are filed by Quality Engineering. Records applicable to each shipment are held by the Traffic Department. Inspection forms and shipping records are retained for a minimum of two years.

\section{AUDITS - PERFORM AN AUDIT OF EACH ERDA CONTRACTOR AT LEAST ANNUALII.Y, AS REQUIRED BY MANUAL CHAPTER 0504.}

Rocky Flats is audited annually by the Operational Safety Division of ERDA's Albuquerque Operations Office to ensure satisfactory performance in the areas of radiation safety, criticality, and packaging. In addition, internal audits are conducted at least semiannually by the Rocky Flats Plant contractor's Quality Engineering Department.

Primary reliance for quality assurance is placed in the receiving inspection conducted at Rocky Flats. All features of package components are readily accessible for inspection and/or testing at this stage. Defective material is returned to the vendor for rework or replacement. Acceptable parts are stocked in the warehouse for issue as needed.

SPECIFICATIONS - DESIGNATE CODES, STANDARDS, MATERIAL SPECIFICATIONS, FABRICATION METHODS, TESTING AND PERFORMANCE REQUIREMENTS.

Drawings listed in the section on Package Definition give all necessary dimensions, standards, and material specifications to produce an acceptable container. Any special fabrication methods or nondestructive tests required are given on the applicable engineering drawings. A formal system of drawing preparation, control, and distribution is defined by the Rocky Flats Product Engineering Manual. Drawings for all waste packaging materials are prepared, issued, and maintained in accordance with this manual.

ACCEPTANCE REQUIREMENTS - ESTABLISH ACCEPTANCE CRITERIA IN TERMS OF MEASURABLE CHARACTERISTICS AND TESTS TO ASSURE THAT ALL PACKAGE DESIGN REQUIREMENTS, INCLUDING PERFORMANCE TESTS (SUCH AS DROP, FIRE, AND IMMERSION), WOULD BE MET BY THE ASSEMBLED CONTAINER.

Inspection and test requirements for the "preliminary determination before use" are itemized on Product Engineering-controlled forms. Typical forms are shown in Figure 11.

SPECIAL PROCESSES - PROVIDE FOR TRAINING, TESTING, AND CERTIFICATION OF MANUFACTURING AND INSPECTION PERSONNEL INVOLVED IN SPECIAL PROCESSES, SUCH AS WELDING AND NONDESTRUCTIVE TESTING, AND FOR THE CERTIFICATION OF EQUIPMENT AND 


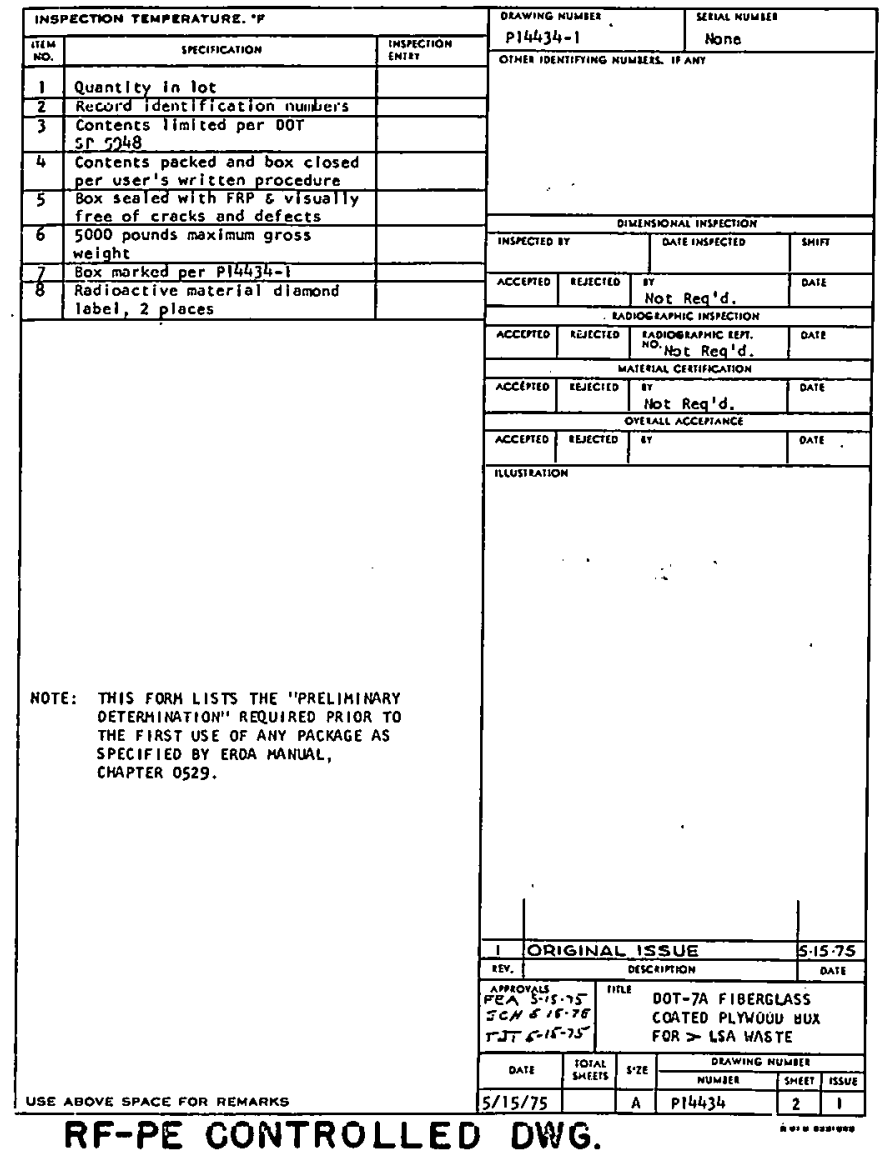

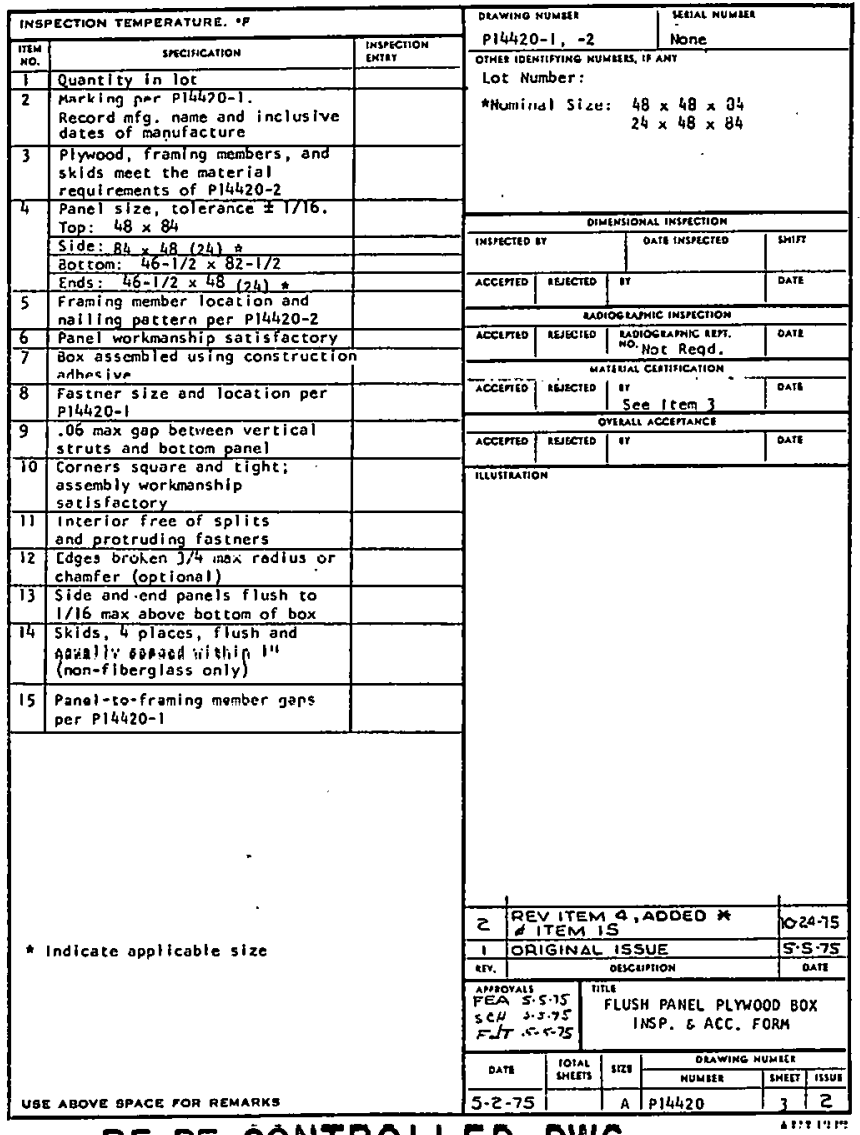

RF-PE COONTROLLED DWG.

FICURE 11. Requirements for inspection are given on forms controlled by product engineering. The form on the left is used for acceptance inspection of new boxes as received trom the manufacturèr. 'The other form is for final inspection of loaded boxes prior to shipment.

\section{PROCEDURES USED IN THE PERFORMANCE OF SPECIAL PROCESSES.}

None of the fabrication or acceptance processes for FRP-coated plywood boxes or box liners are considered "special processes" as defined by ERDA.

USE OF PACKAGE BY OTHER CONTRACTORS PROVIDE DATA TO OTHER ERDA

CONTRACTORS OR LICENSEES WHO MAY USE

THIS PACKAGE TO ASSURE THAT ALL

REQUIREMENTS OF MANUAL CHAPTER 0529

AND 5201 ARE MET.
This document has been furnished expressly to provide all information needed to convey package design intent, to provide data on tests performed, and to define the requirements for fabrication, inspection, and use of this DOT-7A waste package. Before any user ships radioactive material in this container, that user should have n copy of this document and the engineering drawings listed herein. A user shipping Type B quantities of radioactive material must also have the latest applicable revisions of DOT Special Permit 5948 or authorization for an equivalent type of protective outer container. 


\section{A D D E N D U M}

A possible new application for fiberglass-coated plywood crates will be to ship residue or sludge from the evaporation ponds at Rocky Flats. Because of the density of that material, an authorized box gross-weight of 10,000 pounds is desirable. The testing of this heavier box is reported in this addendum.

In the case of heavy (i.e. 10,000-pound) boxes, shipping would be restricted to a one-high array of boxes because of weight limitations on a rail car or highway trailer. Storage would be limited to the bottom layer with no more than 20,000 pounds of stacked weight (four 5000-pound boxes or equivalent) on top. Because of these restrictions, the original 25,000-pound compression test is adequate.

Only the four-foot drop test needs repeating to qualify the heavier box. For this test, a vendorsupplied production box was loaded with sand and gravel to a gross weight of 10,000 pounds. The lid was nailed and glued, and a FRP coating was applied to seal the box. Impact was on a top edge with the box side oriented to make an angle of about $40^{\circ}$ with the horizontal.
The shock of impact separated the sprayed-on FRP closure from the original FRP box sides. Good adhesion was noted on the bare plywood surfaces as evidenced by delamination of the wood in this area. The lack of FRP-to-FRP bonding will be investigated and corrective action taken. It may be significant that the box was eight months old at the time of closing.

Figure 12 shows the box resting on the asphalt roadway and steel-plate impact surface. Note the absence of exposed plywood and the absence of material leakage from the box. Figure 13 shows the uprighted box with the FRP cap pulled back. There was little crushing of the plywood and only a slight deformation of the framing members.

Although the test package did develop a leak path, as illustrated in Figure 14, no material was released. It can be concluded that a similar impact under actual transport conditions would result in negligible loss of radioactive material from the package and no leakage from the vehicle. Package performance at a gross weight of 10,000 pounds is adequate; however, rigid administrative controls must be exercised to assure proper loading, handling, and securing within the transport vehicle. 
FIGURE 12. Inverted box immediately after drop. Plywood crushing was minimal; there was no loss of contents.

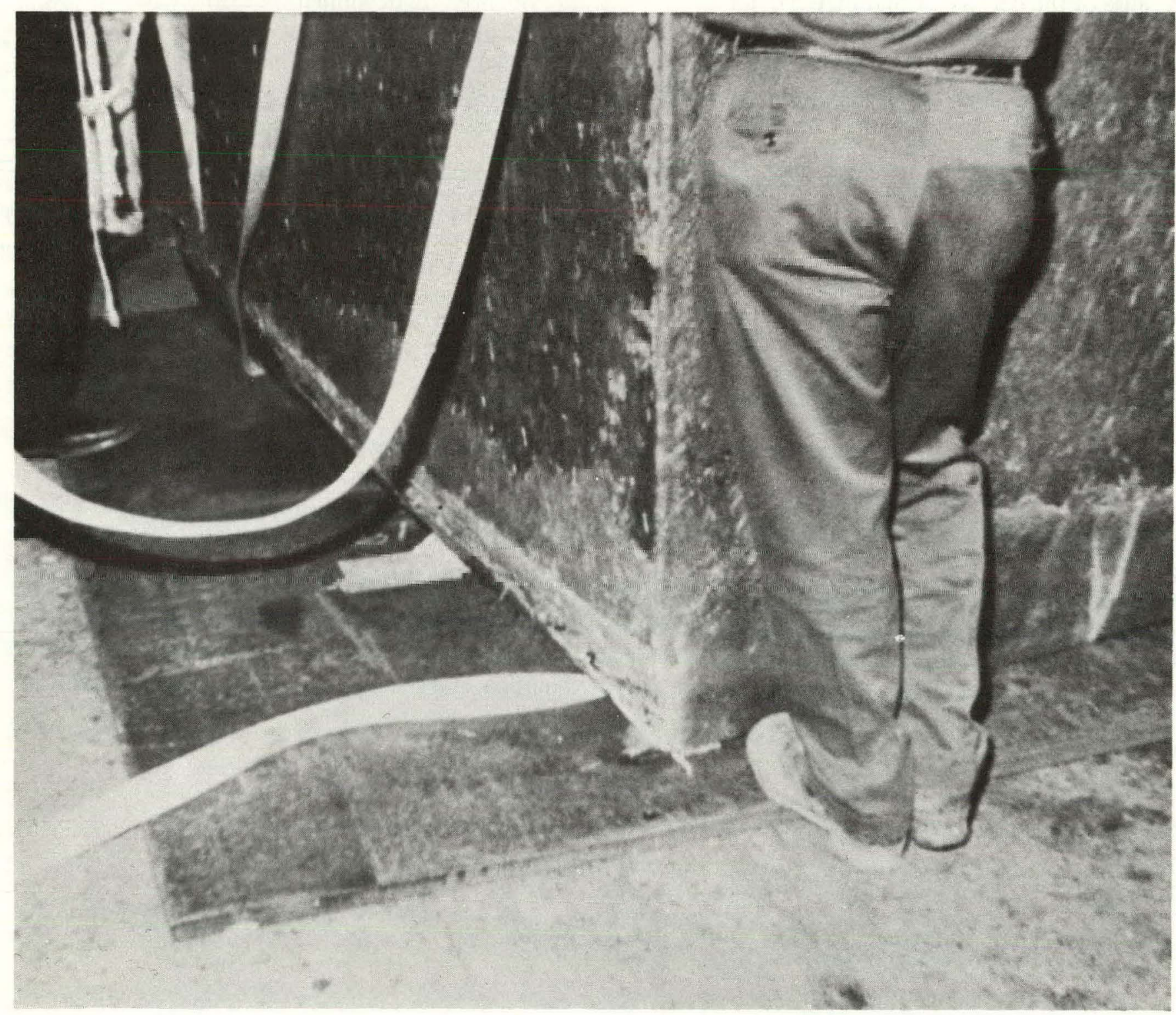




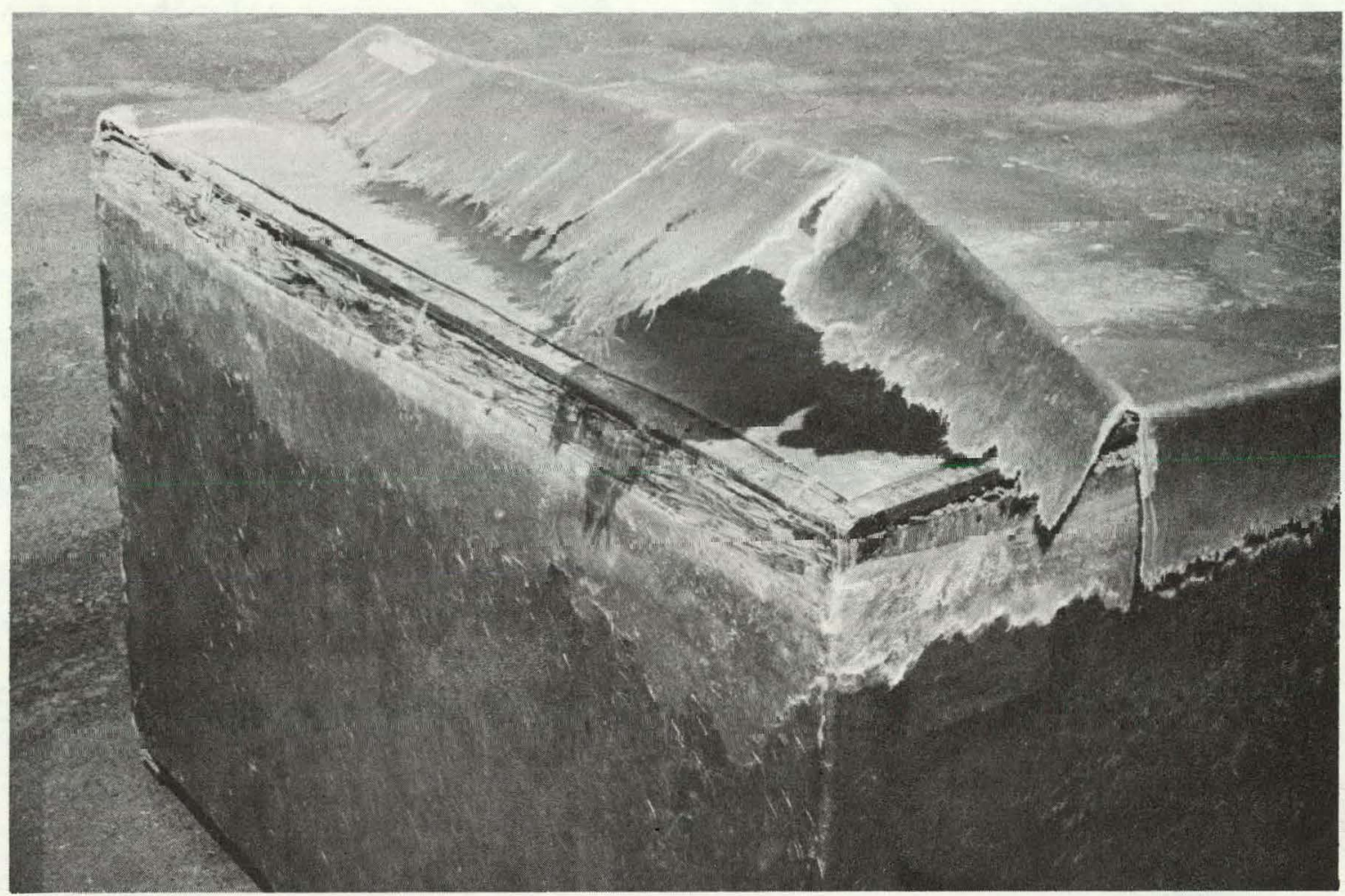

FIGURE 13. Damaged box with cracked FRP cap removed to show condition of plywood

FIGURE 14. Typical cross section of 10,000-pound box showing damage from four-foot drop

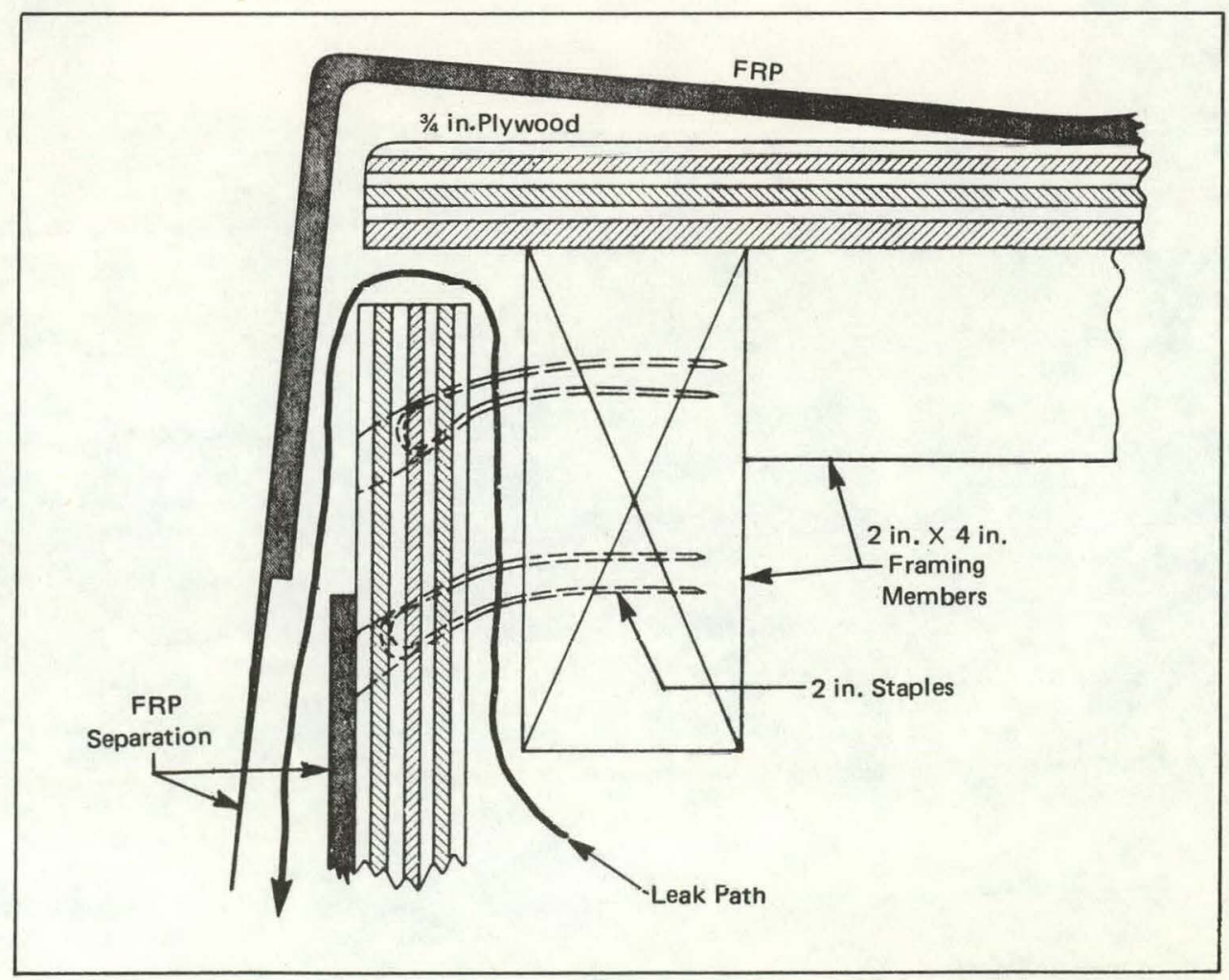




\section{THIS PAGE WAS INTENTIONALLY LEFT BLANK}

